竹下 裕隆 $\begin{gathered}\text { 北九州市立若松病院外科 } \\ \text { 副島 淳一 } \\ \text { 九州大学第 } 2 \text { 病理 }\end{gathered}$ 岸川 英樹
山 口 $\quad$ 幸 二

\title{
A CASE REPORT OF GALLBLADDER CARCINOMA WITH SALMONELLA PARATYPHI A IN THE BILE
}

\section{Hirotaka TAKESHITA, Junichi SOEJIMA, Hideki KISHIKAWA and Kohji YAMAGUCHI*}

Department of Surgery, Kitakyushu Municipal Wakamatsu Hospital

*The Second Department of Pathology, Kyushu University School of Medicine

索引用語：胆襄癌，パラチフス $\mathrm{A}$ 菌, 腺扁平上皮癌

\section{I. 緒}

胆喜癌に併存する率の高い疾患として, 胆石症・胆 䔻腺腫・先天性胆道拡張症・膵管胆道合流異常などが 挙げられるが, 最近になりチフス保菌者の肝胆道系癌 併存例の報告が散見されるようになってきた。

今回, 術中採取胆汁の細菌培養においてパラチフス A 菌陽性であった胆石併存胆栾癌の 1 例を経験した ので，若干の文献的考察を加えて報告する.

\section{II. 症例}

患者：63歳，女性.

既往歴：18歳, 肺結核, 38歳, ネフローゼ症候群.

家族歴・生活歴：特記すべきことなし.

現病歴： 4 年前より年 $1 \sim 2$ 回の頻度で心窩痛が出 現していた，疝痛発作であったが，発熱や黄㾝は伴わ ず自然に軽快していた，今回精査を希望して来院し， 超音波検查で胆石症扣よび胆㿥腫瘍疑の診断で1984年 7 月 24 日当科に入院した。

現症：貟血・黄疸なく, 頸部・胸部に異常所見はな かった。腹部は平坦, 軟で沢田 $G$ 点に圧痛を認めたが, 腫瘤・肝・脾ともに触知しなかった。腹水なく, Virchow 転移や Schnitzler 転移も認めなかった。

検查所見：Carcinoembryonic antigen (CEA) が27 $\mathrm{ng} / \mathrm{ml}$ と高值を示した以外に異常所見は認められな かった（表1）.

$<1987$ 年 4 月15日受理 >別刷請求先：竹下 裕隆 干105 港区虎/門 2-2-2 虎の門病院消化器外 科
表 1 検查成績

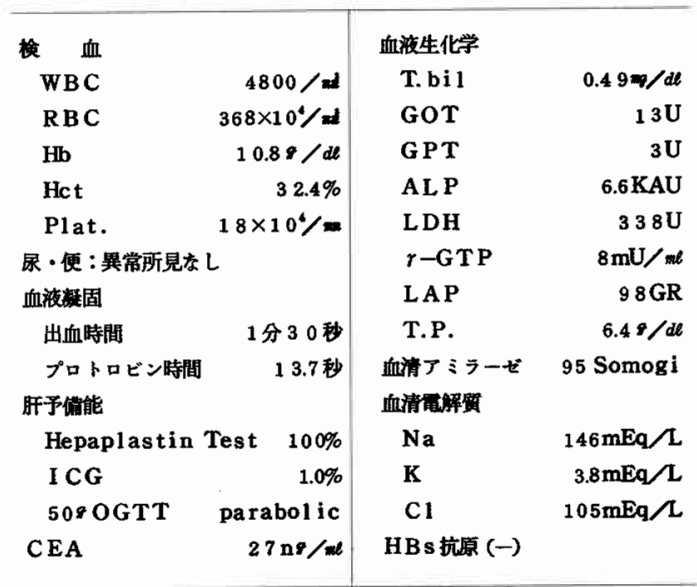

腹部超音波：内部に胆石と思われる 2 個の strong echoを認めた，胆亳壁は不規則に肥厚しており，とく に肝床側は結節状に内腔に突出し周囲の肝は不均一な

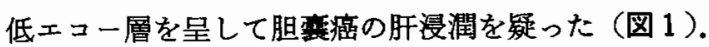

Drip Infusion Cholangiography (DIC)：胆裴の描 出は不良で, 結石を含め詳細不明であった。総胆管は 直径 $12 \mathrm{~mm}$ と軽度拡張していた。

腹部 computed tomography (CT)：胆䓯壁の不規 則な肥厚を認め内腔は狭小化しており, 内部に 2 個の 胆石を認めた。胆旁周囲の肝は低吸収域となっている が癌浸潤か资症の波及かの鑑別は困難であった。肝転 移の所見はなかった（図 2 ）. 
図 1 腹部超音波. 胆霊内に結石像（左）と肝床側腫 瘤（右）を認める。

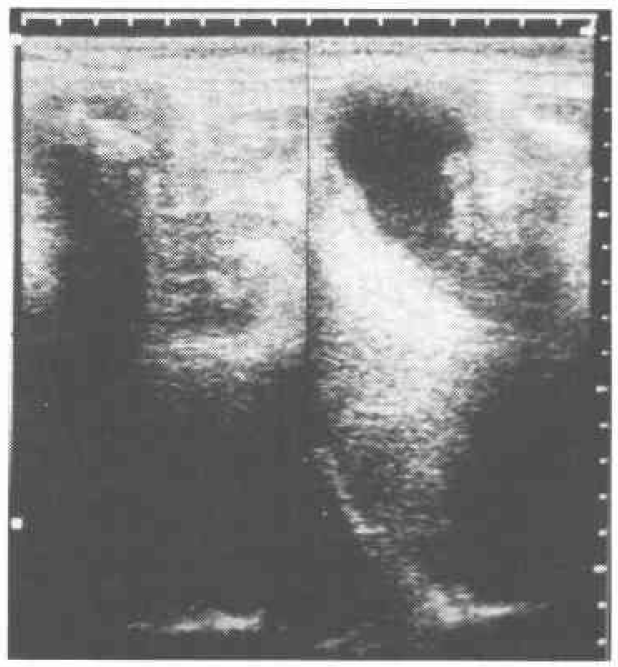

図 2 腹部 CT. 胆霊内にリング状の結石像と不規則 な壁肥厚を認める。胆鸾周囲の肝に low density area 認める。

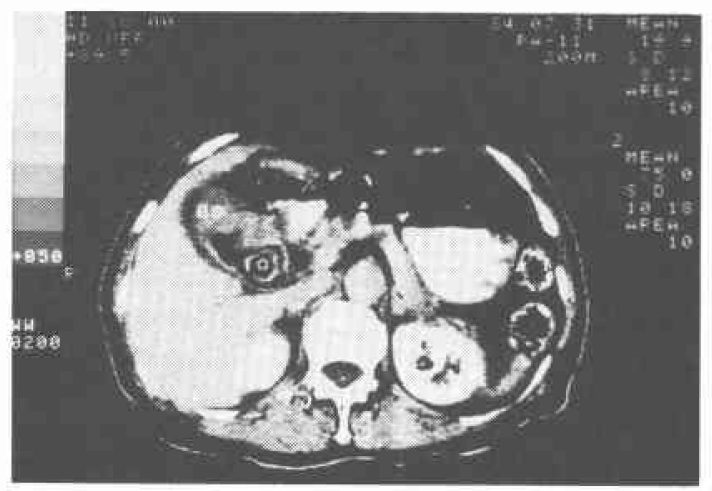

手術所見：開腹時, 腹水・腹膜播種は認められず術 中超音波でも肝転移の所見はなかった、肝門部・肝十 二指腸勒帯にリンパ節腫脹は認めなかった，胆囊は腫 大し，壁肥厚著明だが肉眼的桨膜浸潤はなかった。胆 囊摘出術にリンパ節郭清 (R2) と肝床切除術を加兄た， いわゆる抬大胆囊摘出術 (Glenn's operation) を行っ た。胆道癌取扱い規約 ${ }^{1)}$ にれば, $\mathrm{N}(-)$, So, Po, Ho, Hinfo, Bo, Stage I 絶対治癒切除であった。 病理所見：胆変内にビリルビンカルシウム石 3 個を 認めた。胆囊体部に結節性隆起 $(4.5 \times 5.5 \mathrm{~cm})$ を認め 周囲胆囊壁は線維性に肥厚し肉眼的には結節浸潤型を 呈していた(図 3). 組織学的には中分化腺癌に, 角化
図 3 切除標本。胆囊壁は全体的に肥厚し, 胆囊体部 肝床側を結節性隆起 $(4.5 \times 5.5 \mathrm{~cm})$ を認めた。

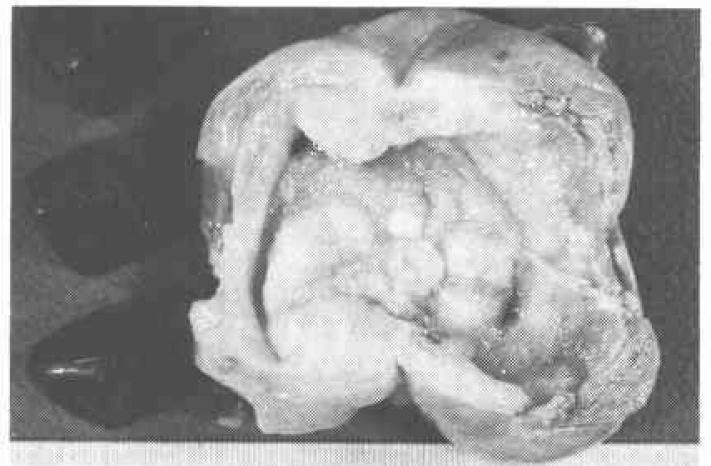

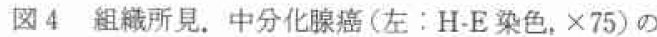
一部に角化を示可扁平上皮福 (右: H-E 染色, X 150)を伴なら腺扁平上皮癌でる。

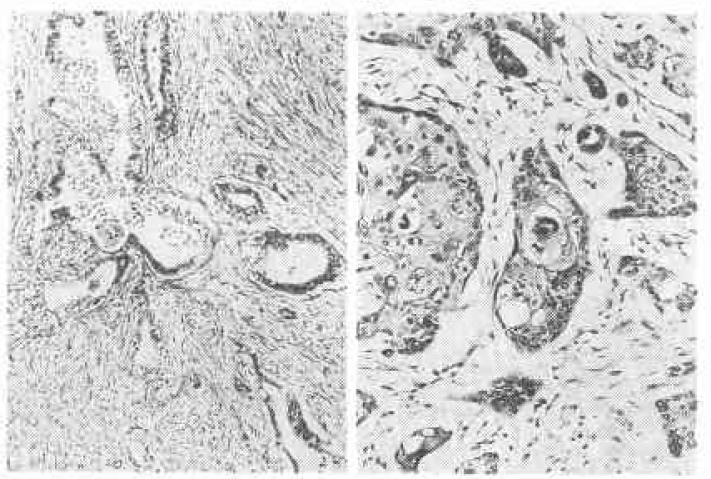

や細胞間橋を伴う扁平上皮癌の成分を有する腺扁平上 皮癌であった（図 4 ）。深達度はssで肝床への浸潤はな く(hinfo)，12cへのリンパ節転移を認めた $\left(\mathrm{n}_{1}(+)\right)$,

経過：術中採取胆汁より Salmonella Paratyphi A が検出されたため直ちに隔離した，術後感染予防とし て投与していた抗生物質 (CFX) に感受性が高く, Widal 反応 (一), 各種培養 (一) で排菌は認められず パラチフスは治癒したものと考兄られた，術後経過良 好にて，20病日目に退院した。術後 5 力月で肝転移を きたし，術後11カ月で死亡した。剖検は行われなかっ た.

\section{III. 考 察}

本邦における腸チフス・パラチフスは戦後激減し, 最近では腸チフスが年間 300 人程度, パラチフスが年間 100 人程度の発生をみている。これらは, 海外に执いて 
感染発症するものと国内での排菌性保菌者によると考 えられるものに大別されるが，後者ではその大部分が 胆道系長期保菌者であるといわれている。

胆道系長期保菌者の大部分は結石を有しており, 有 石率は95.3\% ${ }^{21} ， 97.8 \%^{3)}$ 報告されている。また唐木 ら3)の報告によ礼ば，保菌者92例中68例 (73.9\%) は明 らかなチフス泩疾患の既往歴を持っておらず，大部分 が発病者の家族, 接触者または調理業職従事者などの 検便により発見されているという。一方, 胆石症手術 時の胆汁細菌培養に抢けるチフス菌検出の頻度は低 く, 中野ら ${ }^{4)}$ にると1,176検体中 7 例 (S. typhi 5, S. paratyphi B 2) で0.59\%の割合であったという.

ところで最近になり胆道系チフス保菌者と胆道系腫 瘍（とくに胆囊癌）との併存例の報告が散見されるよ らになってきた223(5) 10). 本邦では自験例を含めても 14 例にすぎない。これらの多くは臨床病理学的事項の記 載もそしく症例呈示にとどまっているため今回は集計 牤よび検討には至らなかった。

文献的にみると, Welton ら 胆道系癌死亡例の頻度について言及して打り，1,004例 の保菌者の追跡調查を行い肝胆道系癌死亡率は $5.9 \%$ で, コントロール群の $1.0 \%$ に比べ有意に高い $(\mathrm{p}<$ 0.001) と述べている。亦た，同論文中に引用されてい る Vogelsang, Beck らの報告でもそれぞれ $8.5 \%$ ， $6.1 \%$ と高率であったという(表 2 ).

本邦に括㚈る胆道系チフス保菌者之胆襄癌の関係に ついては, 松峯 ${ }^{8)}$ と唐木ら ${ }^{3)}$ が言及しており, 東京都立 墨東病院 (松峯) では36例中 4 例 (11.1\%), 東京都立

表 2 チフス菌保菌者と肝胆道系癌死亡例の頻度

\begin{tabular}{|c|c|c|c|c|c|}
\hline 報 告 者 & 年度 & 保蔽者轱数 & 保蔽者死亡测 & 慗死亡㤡 & 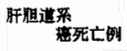 \\
\hline Vogelsang & 1950 & 71 & 47 & $\left(\begin{array}{c}8 \\
(17 \%)\end{array}\right.$ & $\left(\begin{array}{c}4 \\
(8.5 \%)\end{array}\right.$ \\
\hline Beck & 1962 & & 210 & $\begin{array}{c}33 \\
(15.7 \%)\end{array}$ & $\begin{array}{c}13 \\
(6.1 \%)\end{array}$ \\
\hline Wel $\tan ^{6}$ ) & 1979 & 1. 004 & 471 & $\begin{array}{c}102 \\
(21.7 \%)\end{array}$ & $\begin{array}{c}28 \\
(5.9 \%)\end{array}$ \\
\hline
\end{tabular}

表 3 胆道系チフス保菌者と䏣䓦癌

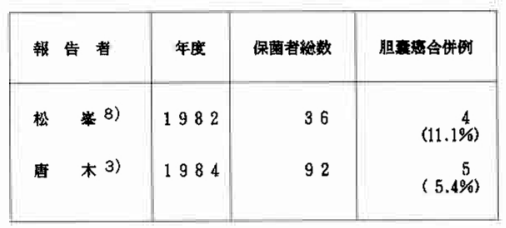

豊島病院（唐木ら）では92例中 5 例 $(5.4 \%)$ の頻度で あったといら(表 3)。胆石症手術症例に和ける胆囊癌 の頻度は $5.0 \%{ }^{11)}$ であり, 胆道系チフス保菌状態は胆石 症之同様, 胆霊癌に抢ける注意すべき risk factor と言 えよう。

チフス菌保菌者と胆霊癌の因果関係についてはいる だ明らかではない. Lowenfels ${ }^{12}$ は胆道閉塞による胆 汁鬱滞之細菌感染により胆汁酸組成の変化が生じ car cinogen となり癌が発生するといら仮説をたてている が, 現在のところ推論にすざない(13) 15)。松峯8)は非癌 例, 担癌例を含めたチフス保菌者摘出胆囊の病理組織 学的検討を試みている．両者ともにリンパ球，形質細 胞浸潤やリンパ濾胞増生の著しい慢性胆囊炎の所見を 呈すが，化生性変化が強く全体の $40 \%$ に腸上皮化生が 存在するとして括り，腸上皮化生を生じやすいチフス 保菌者胆輷炎が胆囊癌発生にかかわる重要な要因では ないかと推測している.

現在, 胆道系チフス保菌者の治療としては, 有石例・ 胆囊造影不良例に外科治療（胆囊摘出と化学療法）を 行い, 胆震造影に異常のない者や手術不能例が化学療 法の適応とされている. 有石例では silent stoneが多 いとされるが，結石は排菌原であることが多いため確 実な結石除去を行う必要がある。

唐木ら゙による, 手術療法をたは化学療法および 両者の併用により74例中70例 (94.6\%) が治窟してい る。結石部位別にみると, 胆襄結石の治癒率は $98.5 \%$ であったが，胆管結石を有すると $62.5 \%$ となり不良で ある、したがって胆囊摘出を原則とし, 胆管に結石ま たは桩張を有する症例には総胆管切開を行い, 小結石 遺残の疑があれば乳頭形成を行うべきであるとしてい る.

\section{IV. 結 語}

胆石併存胆囊癌患者で, 術中採取胆汁の細菌培養で パラチフス $\mathrm{A}$ 菌が検出された症例について報告した。

胆道系長期チフス保菌状態は，チフス菌感染による 化生変化の強い慢性胆囊炎に加之, 高率の胆石併存之 いら因子が加わって㧍り, 胆囊癌の重要な risk factor と考兄られるため積極的な検索と外科治療が望ましい と思われた。

\section{文嗝}

1) 日本胆道外科研究会編：胆道癌取扱い規約. 東京, 金原出版, 1981

2) 北村正次, 小野寺時夫, 伊藤一二ほか：パラチフス $\mathrm{B}$ の胆蘦癌合併例。最新医 $36: 387-390,1981$ 
3）唐木一守, 松原義雄 : 腸チフス・パラチフス胆道系 長期保菌者の外科的療法. 日消病会誌 $81: 2978$ $-2985,1984$

4）中野徹, 田畑正久, 大蕪久憲ほか：胆道疾患と于 フス菌. 外科 $46: 380-384,1984$

5) Axelrod L, Munster AM, O'Brien TF: Typhoid cholecystitis and gallbladder carcinoma after interval of 67 years. JAMA $217: 83,1971$

6) Welton JC, Marr JS, Friedman SM: Association between hepatobiliary cancer and typhoid carrier state. Lancet $11: 791-794,1979$

7) Karsenty C, Delmont J : Cancer de la vésicule biliaire et portage chronique de salmonelles. Gastroenterol Clin Biol 5 : 353-354, 1981

8）松峯敬夫：胆変癌発生とチフス菌。医のあゆみ $123: 247-248,1982$

9）鈴木紳一郎, 吉田 明, 熊本吉一ほか：腸チフス菌 が胆汁中に検出された胆変癌の 1 例。臨外 39 ： $1787-1789,1984$

10）大嶋 隆,高木雄二, 猪野睦征はか：早期胆哓癌を
合併した晹チフスの 1 例. 日臨外医会誌 47 ： $110-113,1986$

11）中山文夫, 古賀明俊, 西浦三郎ほか：胆石症之胆严 癌一胆囊癌の発生と関連して一. 消外 5 : $159-163,1982$

12) Lowenfels AB: Does bile promote extra-colic cancer?. Lancet $29: 239-241,1978$

13) Fortner JG: The experimental induction of primary carcinoma of the gallbladder. Cancer $8: 689-700,1955$

14) Kowalewski K, Todd EF : Carcinoma of the galbladder induced in hamsters by insertion of cholesterol pellets and feeding Dimethylnitrosamine (35293). Proc Soc Exp Biol Med $136: 482-486,1971$

15) Enomoto $M$, Naoe $S$, Harada $M$ et al: Carcinogenesis in extrahepatic bile duct and gallbladder-Carcinogenic effect of N.Hydroxy-2. Acetamidofluorene in mice fed a "gallstoneinducing" diet. Jpn J Med $44: 37-49,1974$ 